Meta

Journal des traducteurs

Translators' Journal

\title{
Explicitation in Medical Translation: A Corpus Study
}

\section{Miguel Jiménez-Crespo}

Volume 60, numéro 2, août 2015

$60^{\mathrm{e}}$ anniversaire. Les horizons de la traduction : retour vers le futur

$60^{\text {th }}$ Anniversary. Translation's Horizons: Back to the Future

60mo aniversario. Los horizontes de la traducción: regreso al futuro

URI : https://id.erudit.org/iderudit/1032894ar

DOI : https://doi.org/10.7202/1032894ar

Aller au sommaire du numéro

Éditeur(s)

Les Presses de l’Université de Montréal

ISSN

0026-0452 (imprimé)

1492-1421 (numérique)

Découvrir la revue

Citer ce document

Jiménez-Crespo, M. (2015). Explicitation in Medical Translation: A Corpus

Study. Meta, 60(2), 343-343. https://doi.org/10.7202/1032894ar d'utilisation que vous pouvez consulter en ligne.

https://apropos.erudit.org/fr/usagers/politique-dutilisation/ 


\title{
Explicitation in Medical Translation: A Corpus Study
}

\author{
Miguel Jiménez-Crespo \\ Rutgers University, New Brunswick, United States \\ Miguelji@rci.rutgers.edu
}

The translation of general medical information represents a case of expert to non-expert communication where lexical and syntactic usage has to be adjusted to the expectation of end users (Montalt and Davis 2007). Nevertheless, research has shown common lexical and syntactic shifts between translated and non-translated texts. These shifts often result in translated medical texts being difficult to understand (Askehave and Zethsen 2003; Raynor 2007; Jensen and Zethsen 2012). For example, in a study of the lay-friendliness of patient information leaflets, Jensen and Zethsen (2012) found that, in language combinations with different lexical density of Latin-Greek (LG) terms, medical professionals tend to translate using higher percentage of LG terms than translators. Similarly, Jiménez-Crespo and Tercedor (2014) found, in a comparable corpus study, that general medical texts translated from English into Spanish contain 3.1 times less LG terms than similar non-translated texts.

This study addresses the issue of explicitation as a general tendency in translation (Baker 1995; Chesterman 2004) that might appear in translated medical texts from English into Spanish in the USA. Due to the need for lay friendliness, it could be hypothesized that additional translation-inherent or other types of explicitation (BlumKulka 1986; Kruger 2014) should be helpful towards the goal of improving expert to patient communication. The study uses the comparable TWCoMS (Translational Web Corpus of Medical Spanish), a 40-million corpus of translated general medical websites into Spanish alongside non-translated medical websites originally produced in Spain and Mexico.

The analysis focuses on both optional syntactic explicitation (Olohan and Baker 2000) of personal pronouns, as well as potential explicitation in reformulations of Latin - Greek terms, in order to compare non-translated reformulations with translated ones, i.e. "dyspnea, shortness of breath."

Miguel Ángel Jiménez-Crespo holds a PhD in Translation and Interpreting Studies from the University of Granada, Spain. He is an Associate Professor in the Department of Spanish and Portuguese, Rutgers University, and he directs that MA in Spanish Translation and Interpreting. He is the author of Translation and Web Localization published by Routledge and his papers have appeared in Translation Studies journals such as Target, Meta, Perspectives, Lingüistica Antverpiensia, TIS: Translation and Interpreting Studies, Jostrans or Translation and Interpreting. He is the assistant editor of the upcoming John Benjamins journal JIAL: the Journal of Internationalization and Localization. His research focuses on the intersection of translation theory, digital technologies, the WWW and corpus-based translation studies. 